\title{
Potential Fiscal Revenues From Hydrocarbon Extraction for the Tourism Region of the Canary Islands
}

\author{
Carmen D. Álvarez-Albelo ${ }^{a}$
}

\begin{abstract}
Hydrocarbon exploration that recently took place in the Canary Islands has triggered a controversy over the compatibility between these activities and tourism. Such exploration was strongly rejected by the region, while being supported by the Spanish government. Many environmental and economic impacts of hydrocarbon extraction were explored, except the fiscal revenues, which represent the main benefit for the producing economies. In this paper, the author addresses this missing piece in the controversy, namely, the assessment of fiscal revenues from hydrocarbons for the Canary Islands. To evaluate these revenues, the author estimates an oilfield production profile, constructs oil and gas price scenarios, and considers the new Spanish tax on hydrocarbons. The estimates are also placed in the socio-economic context of the archipelago. The results show less than overwhelming annual fiscal revenues, below $0.7 \%$ of GDP, $10.4 \%$ of current public transfers to the region, and $5 \%$ of current public spending in 2015. These revenues could be welcome, as the region lags behind the rest of the nation in living standards. However, these benefits from exhaustible resources must be compared to the potential damage to the tourism sector, which has been a long-standing economic driving force for the archipelago.
\end{abstract}

\section{Keywords}

Canary Islands, hydrocarbon extraction, tourism, controversy, fiscal revenues from oil and gas

The Canary Islands is a Spanish region located $95 \mathrm{~km}$ from the southern coast of Morocco and $940 \mathrm{~km}$ from the European continent. Besides facing high transport costs due to its remoteness and territorial fragmentation, the region also lacks the resources, such as water and arable land, and scale economies to develop competitive agricultural and/or industrial sectors. In order to mitigate these obstacles to development (Guillaumont 2010), the archipelago enjoys the favorable condition of outermost region of the European Union. Even so, its mild weather and natural features have made the region a successful international tourism destination. Due to the high dependence on foreign tourism, any event that may reduce tourism demand could be viewed as a serious threat to economic development and the population's living standards.

In 2014, the region was shaken by this type of event, namely, the potential discovery of an offshore hydrocarbon reserve. Well-known environmental disasters caused by oil spills and their negative economic impacts (Chang et al. 2014) set the alarm

\footnotetext{
aUniversidad de La Laguna, Spain

Correspondent Author:

Carmen D. Álvarez-Albelo, Departamento de Economía, Contabilidad y Finanzas, Campus de Guajara, Universidad de La Laguna, 38071 La Laguna, Canary Islands, Spain
} 
bells ringing in the archipelago. The grant by the Spanish government of an exploration license to a private oil company and the subsequent prospection work faced strong social and institutional rejection, which gave rise to controversy and disputes between the Spanish government and regional stakeholders.

The local government and the councils of the two islands nearest to the exploration area-Fuerteventura and Lanzarote - presented their arguments against hydrocarbon development in a public document (Gobierno de Canarias, Cabildo de Fuerteventura, and Cabildo de Lanzarote 2013). This document was aimed at informing the population of the potential negative impacts of hydrocarbon exploration and production. Moreover, the local government conducted an opinion poll that revealed wide spread rejection of such exploration by three out of four citizens.

Two main sets of arguments against hydrocarbon activities were put forward. The negative environmental impacts were at the forefront, despite the Spanish government and the oil company insisting on the safety of the project. Numerous and varied impacts were explored, such as the possibility of an oil spill and its corresponding clean-up costs, contamination of drinking water, seismic risk in a volcanic territory, or damage to marine species. All of them would seriously harm the population's well-being and also tourism, the leading sector in the archipelago. Even the mere existence of offshore hydrocarbon activities might devaluate the image of the region as a tourism destination, bringing about a contraction of the tourism demand. The second set of arguments was purely economic. Although the Spanish government highlighted the advantages of developing a new economic sector, the local government argued that this sector was expected to create little economic activity and few jobs, since most capital and labor income generated by these activities would go abroad ${ }^{1}$. Importantly, the local government also complained about the lack of a clear fiscal proposal. At that time, the Spanish law on hydrocarbons did not contemplate transfers to the producing regions, so a reform of the law was necessary for the Canary Islands to receive additional fiscal revenues from hydrocarbon production.

The latter issue is far from being unimportant, since fiscal revenues are the main benefit for oil-producing economies (Sunley, Baunsgaard, and Simard 2003). Aware of this fact, the Spanish government expressed its intention of introducing specific taxation in favor of the region, similar to that applied in Italian regions (Rocchi et al. 2015; Iacono 2016). Promised additional fiscal revenues envisaged a kind of compensation to gain social and institutional acceptance of these activities.

Notwithstanding the fact that the exploration was finally abandoned by the oil company, adducing low quality of the reserve, there are reasons to believe that it could be resumed in the future. Thus, the controversy will start over in the case of a resumption of exploration work, with similar arguments on both sides. However, the aforementioned reform of the Spanish law on hydrocarbons took place in 2015 , so a missing piece in the debate, namely, the evaluation of fiscal revenues, should be considered in order to properly assess the costs and the benefits of hydrocarbon exploration and extraction for the archipelago.

The objective of the present work is to perform an estimation of the fiscal revenues from oil and gas that might be received by the Canary Islands, and to place them in the socio-economic context of the archipelago. This further piece of information may even tip the balance in favor of hydrocarbon production. This is so because the archipelago lags behind the rest of the nation in living standards, as it suffers from lower per capita income and social spending, and higher unemployment and poverty rates than other Spanish regions. While regional development cannot be based on the production of exhaustible resources (Bauer 2013), these activities could become a significant 
source of fiscal revenues for a long time period.

Nevertheless, literature has shown that revenues from exhaustible resources could even become a curse (van der Ploeg 2011; Bauer 2013). The so-called Dutch disease is a major concern to this respect (Ismail 2010), since it causes a real appreciation and loss of external competitiveness, which may shrink the tourism sector (Forsyth, Dwyer, and Spurr 2014).

In this paper, the estimation of the potential fiscal revenues for the Canary Islands involves four stages. Firstly, a production profile for the archipelago's oilfield is constructed based on geological appraisals of the reserve and technical literature on this topic. This stage is necessary, as hydrocarbon production and income are far from being stable over time. Moreover, taxes are levied on the value of production. Thus, the second stage comprises three scenarios for the future evolution of international prices of oil and gas. The third stage involves a review of the new Spanish law on the hydrocarbon sector, which includes tax rates levied on these activities. The fourth stage estimates the fiscal revenues using the previous outcomes, and places the results in the socio-economic context of the Canary Islands.

The remainder of the paper is organized as follows. The second section describes the background and future prospect of hydrocarbon projects in the Canary Islands. The abovementioned four stages of the analysis are performed in sections 3 through 6 , respectively. Lastly, section 7 offers the conclusions.

\section{HYDROCARBON EXPLORATION IN THE CANARY ISLANDS: BACKGROUND AND FUTURE PROSPECTS}

In November 2014, the oil company Repsol began exploration works in the ultra-deep waters $(3,100 \mathrm{~m})$, at around $50 \mathrm{~km}$ from Fuerteventura and $61 \mathrm{~km}$ from Lanzarote.

It was the end stage of an ongoing process, since the first exploration license went back to 2001 .
However, from the very beginning, the local authorities and stakeholders have litigated in court against the national government to stop the project. As a result, in 2004, the license was revoked by the Spanish Supreme Court, alleging that an environmental report presented by the oil company did not meet with the legal requirements (Gobierno de Canarias et al. 2013). Since then, the national government has continued to take actions in favor of the project, while the local government and stakeholders have tried to halt it. However, in 2014, the latter group failed in the goal of stopping exploratory drilling operations.

The information provided by Repsol to the general public highlighted the environmental safety of the project, and also the economic benefits for both the region and the nation. According to the oil company, the regional economy could profit in terms of job creation and higher economic diversification, while the nation could save $10 \%$ of its oil imports in 10 to 20 years. No less important was the statement by the Spanish Minister of Industry, Energy and Tourism that, in the event of discovery and subsequent production, the Canary Islands would benefit from the introduction of specific taxation on these activities, similar to that applied in the Italian region of Basilicata (Rocchi et al. 2015; Iacono 2016). As mentioned, it seemed that the aim of this taxation was no other than to overcome the strong social and institutional opposition to these activities in an archipelago that is highly dependent on tourism.

However, the project finally turned out to be shortlived. The exploration work was expected to last for four months, but after two months, the oil company decided to abandon it, seal the well, and give up the exploration license. The company adduced that the gas found did not have the required quality to be exploited.

Despite the clear-cut statement of the oil company, there are reasons for not ruling out future exploration. Indeed, the company had permission to explore three 
points, but only one of them was explored. Moreover, the whole offshore area with potential hydrocarbon resources is not limited to the aforementioned exploration points, but is clearly more extensive, including nine grids along the coast of Fuerteventura and Lanzarote. The area is close to the Moroccan coast, where oil exploration has taken place actively in the past, and is expected to continue in the future (Taib 2015).

It also seems logical to relate the hasty departure of the company with falling oil prices in the international markets (World Bank 2017), which significantly reduce the profitability of hydrocarbon projects. The company denied that this was a reason for giving up the exploration license, but this is undoubtedly a powerful one.

Another reason not to discard future exploration is the high energy dependence of Spain (Galdón Ruiz, Soucause, and Pradas 2016), which points to the advisability of exploring hydrocarbon resources in the national territory.

\section{ESTIMATE OF AN OILFIELD PRODUCTION PROFILE IN THE CANARY ISLANDS}

Although the existence of a hydrocarbon reserve with enough volume and quality to be exploited is uncertain, there are estimates of Gessal (2013) made for the whole country, including the Canary Islands. For reliability, the author uses these estimates, which were performed under rigorous geological criteria.

The study by Gessal (2013) divides the Spanish territory into 24 domains, where domain 7 corresponds to the Canary Islands. For this domain, a reserve of conventional hydrocarbons - not using fracking — of 1,200 million barrels of oil (MBO) and 226 billion cubic meters (BCM) of natural gas has been estimated. These figures indicate that the bulk of conventional hydrocarbon reserve in Spain would be concentrated around the Canary Islands. More specifically, for oil and natural gas, the archipelago would have $61.73 \%$ and $55.12 \%$ of national conventional reserves, respectively. According to the classification of offshore oilfields, this is a large reservoir. Indeed, an oilfield is considered as giant when it has an ultimately recoverable reserve (URR) - estimate of the quantity that could ever be recovered and produced from an oilfield - greater than 500 MBO (Höök et al. 2009).

As previously expounded, estimating the fiscal revenues for the region requires constructing the production profile, as hydrocarbon production is far from being stable over time. The estimates of a production profile for oil and gas in the Canary Islands in Figure 1 rely on the theoretical and empirical literature on this topic. More specifically, the author uses the Gauss formula in Laherrère (2000), after including a slight modification by Kato, Omachi, and Aso (2002) to capture the asymmetry of a typical profile (Brandt 2007). This is a suitable approach to represent a giant field in a hydrocarbon-bearing region, which is usually composed of many independent reservoirs $^{2}$. The formula is expressed as follows:

$$
P_{t}=\frac{2 U R R_{i}}{\sqrt{2 \pi} s(r+1)} \begin{cases}e^{-\frac{(t m-t)^{2}}{2 s^{2}}} & \text { if } t m>t \\ e^{-\frac{(t m-t)^{2}}{2 r^{2} s^{2}}} & \text { if } t m \leq t\end{cases}
$$

with $i=$ oil,gas

Where, $s$ is the standard deviation, $t m$ is the peak period of maximum production, $t$ is time, and $r$ is the parameter of asymmetry. In the formula, power takes two different expressions to control for the asymmetry. The author calibrates this formula by taking into account the URR of 1,200 MBO for oil, and the URR of 1,410 million barrels of oil equivalent (MBOE) for gas. It is worth noting that the URR of $226 \mathrm{BCM}$ for gas has been converted into MBOE in order for oil and gas profiles to be expressed in the same units, where the conversion factor appears in the note of Figure 1. The author assumes that the first oil/gas is produced in 2025. According to the empirical analysis of non-OPEC offshore oilfields by Höök et al. (2009: 
48), $\mathrm{tm}$ is set equal to 13 years. In addition, setting $s=5.44$ and $r=1.3$, it obtains that $46.2 \%$ of the URR is depleted by period 13 , and the depletion rate of remaining reserves at peak ${ }^{3}$ is equal to $11.8 \%$, which agrees with the aforesaid empirical evidence.

\section{OIL AND GAS PRICE SCENARIOS}

The construction of price scenarios for oil and gas is based on the World Bank (2017) commodity forecast price data on crude oil (average spot prices) and natural gas (in Europe), expressed in nominal US dollars per barrel and per million British thermal units (MMBTU), respectively. The World Bank series include actual data from 2014 to 2016, and price forecasts from 2017 to 2025. The author uses conversion factors to express the price of gas in US dollars per BOE.

The author converts these series into euros using the 2002-2016 average exchange rate of .79 euros per dollar ${ }^{4}$. Also, prices need to be expressed in real euros by deflating them with the consumer price index (CPI), so that the price comparison over time makes sense. To do so, the author considers the 2014-2016 CPI of the Canary Islands, with 2015 as the base year. From 2017 onwards, the author assumes a steady inflation rate of $1.59 \%$, which is the average inflation rate in the period 2002-2016 ${ }^{5}$. The series in real 2015 euros are depicted in Figure 2.

Unlike the current downward trend, the World Bank forecast shows an upward trend from 2017 to 2025 , with real prices of oil and gas roughly increasing at $0.83 \%$ and $2.08 \%$ per year, respectively.

The author relies on this price forecast to construct the scenarios on the time-based evolution of oil and gas prices from 2026 to 2060 shown in Figure 2. In the scenario "Low", real prices remain constant during the entire time period, meaning that the nominal prices grow at the same rate as the assumed inflation rate of $1.59 \%$. The scenario "High" considers that real prices grow at the same pace as the figures predicted by the
World Bank adjusted for inflation. Lastly, in the scenario "Middle", the real prices of oil and gas are assumed to grow at constant rates $0.41 \%$ and $1.04 \%$, respectively.

\section{THE SPANISH LAW ON THE HYDROCARBON SECTOR}

The current Law 8/2015, amending Law 34/1998, introduces new taxation on the activities of research, exploration, and production of hydrocarbons.

The Law establishes the social commitment of both the private operator and the state with the regions hosting oilfields, in order for these activities to be compatible with socio-economic development. Along these lines, these regions will benefit from subsidies financed with fiscal revenues arising from three tax figures: the Tax on the Value of Extraction of Gas, Oil and Condensate (TVE), and Tariffs 3 and 4 included in the Surface Canon (SC).

The TVE is a progressive ad valorem royalty (Sunley et al. 2003; Cotarelli 2012), levied annually on the value of the hydrocarbons produced in the national territory. The tax schedules appear in Table 1. A reference price is used to value production, which is computed as a monthly average of prices in the most representative markets for each product. In the SC, Tariff 3 establishes a payment of 600,000 euros and 125,000 euros for each offshore and onshore exploratory drilling site, respectively. Regarding Tariff 4 , it establishes payments of $€ .0003 / \mathrm{m}^{2}$ and $€ .3 / \mathrm{m}$ for $3 \mathrm{D}$ and $2 \mathrm{D}$ seismic studies, respectively.

\section{ESTIMATED TVE REVENUES IN THE SOCIO-ECONOMIC CONTEXT OF THE CANARY ISLANDS}

The author only takes into account the TVE, as it generates the bulk of the fiscal revenues. Regarding the results obtained from this section, it should be kept in mind that variables are expressed in real 2015 euros. 


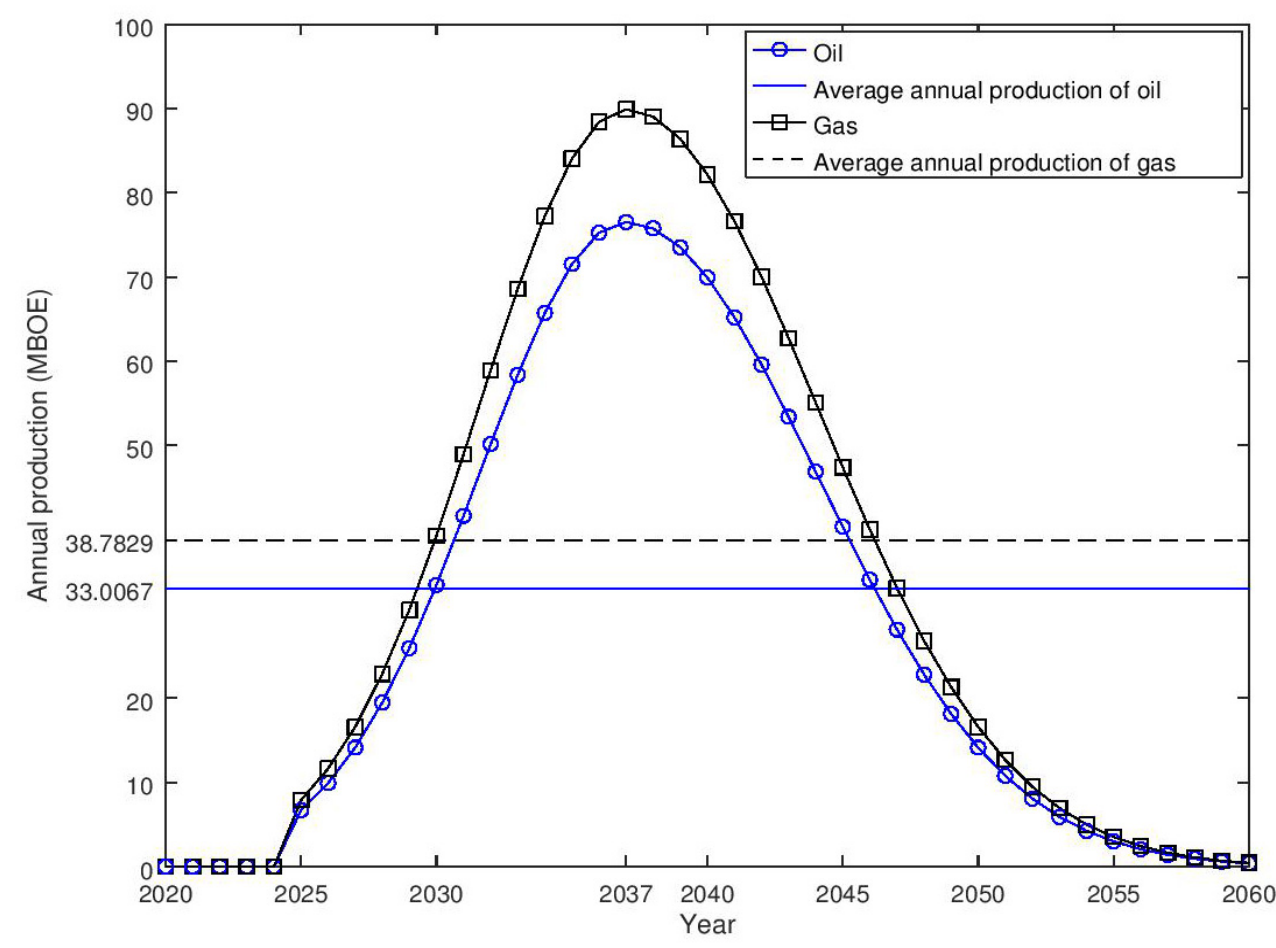

Figure 1. Estimation of Production Profiles for the Oilfield of Canary Islands. Note: One barrel of oil amounts to $160.23 \mathrm{~m}^{3}$ of gas (SPE) ${ }^{6}$.

(a) Price of oil

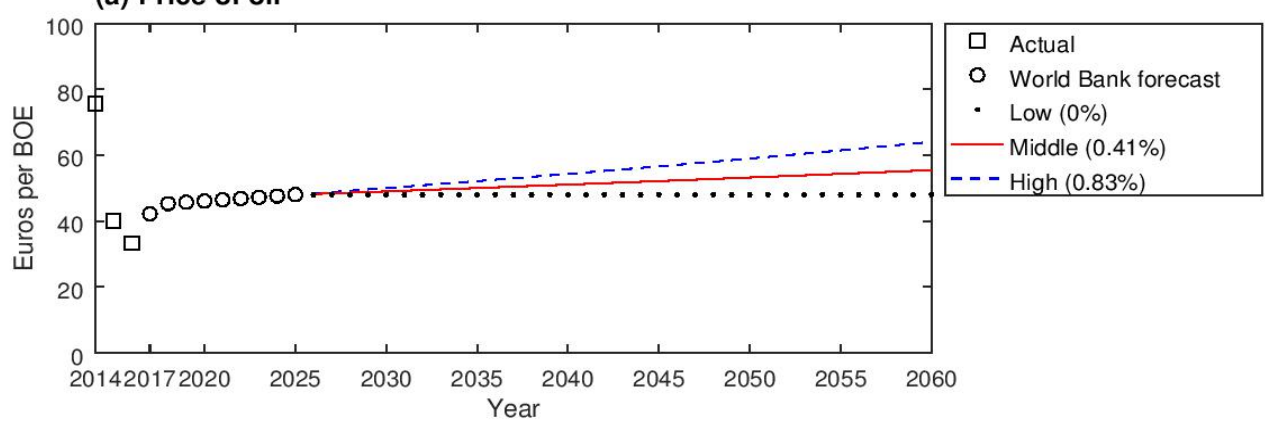

(b) Price of gas

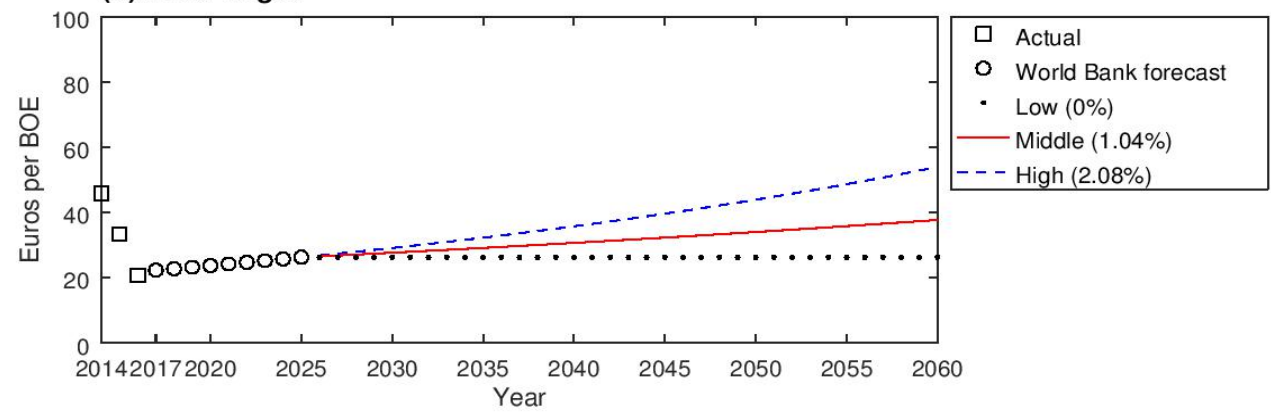

Figure 2. Scenarios on the Evolution of Oil and Gas Prices (Real 2015 Euros).

Notes: Source: World Bank (2017) and the author's own calculations. One barrel of oil amounts to 5.8 MMBTU (SPE). 
Table 1. Tax Schedules in the Spanish TVE (Offshore Production)

\begin{tabular}{ll}
\hline Oil and condensate & Tax rate (\%) \\
\hline Number of barrels (BO): & 1 \\
$B O \leq 365,000$ & 5 \\
$365,000<B O \leq 3,650,000$ & 7 \\
$B O>3,650,000$ & \\
\hline Gas & Tax rate (\%) \\
\hline Volume (V) in number of BOE: & 1 \\
$V \leq 205,017.8$ & 3 \\
$205,017.8<V \leq 1,025,088.9$ & 4 \\
$V>1,025,088.9$ & \\
\hline
\end{tabular}

Note: Source: Spanish Law 8/2015.

The results in Figures 1 and 2, together with the tax schedules in Table 1, allow the author to compute the total TVE revenues obtained from oil and gas produced in the oilfield of the Canary Islands. However, the Spanish Law states that the producing regions will benefit from transfers financed with the TVE, which, of course, does not mean that the regions will earn the totality of tax revenues. This fact forces the author to make assumptions about their distribution between the Spanish state and the Canary Islands. As shown by Arellano-Yanguas and Mejía-Acosta (2014), this distribution could rely more on political than economic issues. Thus, the author opts by considering the distribution in the Italian region of Basilicata, since the Spanish government gave this example in its proposal for a new taxation on hydrocarbon production. In this region, the local government receives $70 \%$ of the overall royalty revenues (Iacono 2016). With this distribution, the government of the Canary Islands would receive the fiscal revenues from the TVE shown in Figure 3.

The total fiscal revenues from oil and gas accrued in 2026-2061 amount to 3,815.7, 4,130.3, and 4,482.1 million euros in the scenarios "Low", "Middle", and "High", respectively, which yield average annual revenues of 123.09, 133.24, and 144.59 million euros. Moreover, revenues in the peak year are equal to 246.11, 263.97, and 283.3 million euros in the respective scenarios.

The last step in the analysis consists of placing the estimates of the TVE revenues in the socio-economic context of the Canary Islands. To do so, the author relies on the information summarized in Tables 2 and 3.

Several indicators in Table 2 reveal that the Canary Islands lag behind other Spanish regions and the nation when it comes to the standard of living. The region ranks first in terms of poverty rate and stands last in social public spending per inhabitant. In addition, GDP per capita is below the national average, and the region ranks second in terms of unemployment rate, with this rate being seven percent points higher than that in the nation. In view of this situation, one could argue in favor of additional public revenues, with the aim of improving the population's well-being.

Nonetheless, care should be taken that the hydrocarbon production does not threaten the future economic development of the region. Indeed, it is worthwhile noting that oil and gas are both exhaustible resources, while tourism is a long-lasting economic driving force. The tourism sector accounted for $31.9 \%$ of GDP, $37.6 \%$ of the employment, and $32.1 \%$ of the tax revenues in 2015 (Exceltur and Gobierno de Canarias 2016). These figures clearly show that damaging this sector could seriously compromise both economic growth and social welfare of the region. 
(a) Oil
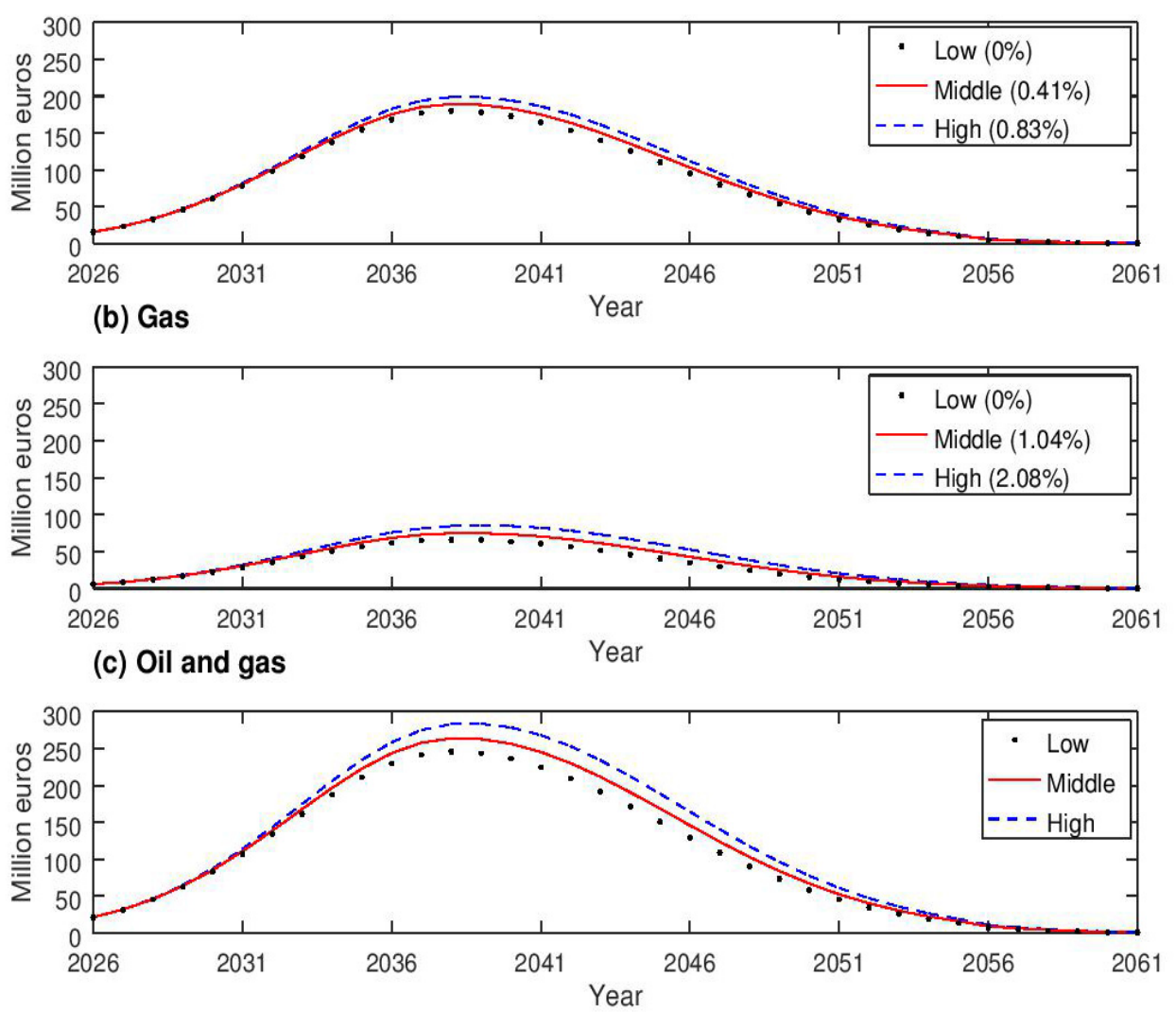

Figure 3. Potential TVE Revenues for the Canary Islands (Real 2015 Euros).

Note: The TVE is payable in the next year of the tax year.

Table 2. Socio-economic Features of the Canary Islands, 2015

\begin{tabular}{|c|c|c|c|}
\hline & Canary Islands & $\begin{array}{l}\text { Regional } \\
\text { ranking (17) }\end{array}$ & Spain \\
\hline Poverty rate ${ }^{a,(1)}$ & .3222 & 1 & .2126 \\
\hline Social public spending per capita (€) ${ }^{\mathrm{b},(2)}$ & $5,252.5$ & 17 & $6,230.2$ \\
\hline GDP (M€)c & $40,880.4$ & 8 & $1,075,639$ \\
\hline GDP per capita $(€)^{c}$ & 19.464 & 13 & 23.070 \\
\hline Unemployment rate $(\%)^{c}$ & 29.11 & 2 & 22.06 \\
\hline Current public revenues $(\mathrm{M} €)^{\mathrm{c}}$ & $5,583.3$ & & \\
\hline Taxes & $2,836.4$ & & \\
\hline Current transfers & $2,737.9$ & & \\
\hline Other revenues & 9.0 & & \\
\hline Current public spending $(\mathrm{M} €)^{\mathrm{c}}$ & $5,704.6$ & & \\
\hline
\end{tabular}

Note: Source: a Málaga and Mayo (2014), b Fundación BBVA and Ivie (2015), and c Canary Islands Statistics Institute; (1) 2013, (2) 2012. 
Table 3. Estimated TVE Revenues in the Economy of the Canary Islands, 2015

\begin{tabular}{|c|c|c|c|c|c|c|c|c|c|}
\hline Scenarios & Low & Middle & High & Low & Middle & High & Low & Middle & High \\
\hline TVE revenues & \multicolumn{3}{|c|}{$\%$ GDP } & \multicolumn{3}{|c|}{$\%$ current public transfers } & \multicolumn{3}{|c|}{$\%$ current public spending } \\
\hline - At peak (2038) & .60 & .65 & .69 & 8.99 & 9.64 & 10.35 & 4.31 & 4.63 & 4.97 \\
\hline - Annual average & .30 & .33 & .35 & 4.50 & 4.87 & 5.28 & 2.16 & 2.34 & 2.53 \\
\hline
\end{tabular}

Regarding the magnitude of TVE revenues in relation to the size of the economy, Table 3 shows that these revenues would represent a small fraction of the regional GDP of 2015. More specifically, it would represent $0.69 \%$ as a maximum in the peak year (2038) and around $0.33 \%$ as the annual average. Hence, a Dutch disease episode can be discarded, as a much higher contribution in terms of GDP is required for this type of phenomenon to take place (Brahmbhatt, Canuto, and Vostroknutova 2010).

The share of TVE revenues in public current transfers is relevant, since regions do not levy the TVE, but receive transfers from the state. The results indicate that TVE revenues could amount to a maximum of $10.35 \%$ of total transfers in the peak year, and around $4.87 \%$ as an annual average. Lastly, these revenues could entail $4.97 \%$ of the current public spending as a maximum, with an annual average around $2.34 \%$.

\section{CONCLUSIONS}

In light of the negative environmental and economic impacts of oil spills, one could argue against the compatibility between hydrocarbon production and tourism. This view was recently shared by the stakeholders of the Spanish tourism region of the Canary Islands, as shown in 2014, when the oil company Repsol began exploratory drilling operations in the archipelago. Exploration was strongly rejected by the region, while being supported by the national government. Notwithstanding that the exploration was finally abandoned, there are reasons for not ruling out future prospecting. Consequently, a complete assessment of the cost and benefits from hydrocarbon production is required for fully-informed decision-making, both at the local and the national levels.

In this paper, the author has addressed a missing piece of information in this controversy, namely, the potential fiscal revenues that the archipelago could receive in case of the discovery and subsequent production of hydrocarbons. The estimation of these revenues is relevant since, as shown by the literature, they entail the main benefit for the producing regions. To assess these revenues, the author has estimated an oilfield production profile for the region, constructed three-price scenarios, and considered the new Spanish tax on these activities. The author has also placed the estimated fiscal revenues in the socio-economic context of the Canary Islands.

The findings show annual fiscal revenues for the Canary Islands below $0.7 \%$ of GDP, $10.4 \%$ of current public transfers to the region, and $5 \%$ of current public spending in 2015. These figures allow discarding a Dutch disease episode.

The region could certainly welcome these additional transfers from the Spanish state, as it lags behind other Spanish regions and the nation in relevant living standard indicators. Nonetheless, the benefits must be compared to the costs, and payments should compensate for the risk taken. In this respect, it should be borne in mind that the fairly low fiscal revenues obtained here would be temporary, whilst tourism is an enduring economic driving force for the archipelago. This is a crucial starting point in the decision-making scene for national and local authorities with regard to future 
hydrocarbon exploration and extraction in the Canary Islands.

\section{Acknowledgements}

Comments and suggestions from Mikael Höök, Marta Merino, and Francisco Ramos-Real are gratefully recognized. The author acknowledges financial support from the Fundación Caja Canarias (CTCEPLA 11). Computing codes used in this paper are available upon request to the author.

\section{Notes}

1. A comprehensive analysis of environmental and economic impacts, with special reference to the tourism sector, can be found in Padrón Fumero et al. (2013). Oil spill risk was analyzed by Gómez et al. (2013). Rivero Ceballos and Corral (2014) performed an economic analysis in terms of uncertainty.

2. The author gratefully recognizes this comment from Mikael Höök.

3. As defined in Höök (2014: 96).

4. From the European Central Bank. Retrieved (https://goo. gl/GVqsg0).

5. From the Canary Islands Statistics Institute. Retrieved (https://goo.gl/XozLCa).

6. Unit conversion factors here and throughout the paper come from the Society of Petroleum Engineers (SPE) website (https://goo.gl/ZcjCSW).

\section{References}

Arellano-Yanguas, J. and A. Mejía-Acosta. 2014. "Extractive Industries, Revenue Allocation and Local Politics." United Nations Research Institute for Social Development, working paper 2014-4.

Bauer, A. 2013. "Subnational Oil, Gas and Mineral Revenue Management." Revenue Watch Institute Briefing, July 2013.

Brahmbhatt, M., O. Canuto, and E. Vostroknutova. 2010. "Dealing With Dutch Disease." Economic Premise 16(June), Washington, D.C.: World Bank.

Brandt, A. R. 2007. "Testing Hubbert." Energy Policy 35(5):3074-3088.

Chang, S. E., J. Stone, K. Demes, and M. Piscitelli. 2014. "Consequences of Oil Spills: A Review and Framework for Informing Planning." Ecology and Society 19(2):26.

Cotarelli, C. 2012. "Fiscal Regimes for Extractive Industries: Design and Implementation.” International Monetary Fund,
Fiscal Affairs Department.

Exceltur and Gobierno de Canarias. 2016. IMPACTUR 2015. Estudio Sobre el Impacto Económico del Turismo sobre la Economia y el Empleo de las Islas Canarias (IMPACTUR 2015. Economic Impact Analysis of Tourism on the Economy and Employment of the Canary Islands). Retrieved (https://goo.gl/tf9MTF).

Forsyth, P., L. Dwyer, and R. Spurr. 2014. "Is Australian Tourism Suffering Dutch Disease?" Annals of Tourism Research 46:1-15.

Fundación BBVA and Ivie. 2015. Las Diferencias Regionales de Gasto por Habitante en Educación, Sanidad y Protección Social se Aproximan al 60\% (Regional Disparity in per Capita Expenditure in Education, Health and Social Protection Are Close to 60\%). Press release, May 2015. Retrieved (https://goo.gl/3drr5q).

Galdón Ruiz, J. A., B. M. Soucause, and I. G. Pradas. 2016. "La Dependencia Energética en España por Sectores y su Impacto Económico" (Energy Dependence in Spain by Sectors and Its Economic Impact). Técnica Industrial 314:46-55.

Gessal. 2013. Evaluación Preliminar de los Recursos Prospectivos de Hidrocarburos Convencionales y no Convencionales en España (Preliminary Assessment of Prospective Resources of Conventional and Unconventional Hydrocarbons in Spain). Madrid: ACIEP. Retrieved (https://goo.gl/VPFFkt).

Gobierno de Canarias, Cabildo de Fuerteventura, and Cabildo de Lanzarote. 2013. Argumentario General. Prospecciones Petroliferas en Canarias (General Arguments. Oil Exploration in the Canary Islands). Retrieved (https://goo. $\mathrm{gl} / \mathrm{Xcro} 9 \mathrm{u})$.

Gómez, J. I., J. M. Calvilla, J. A. González, and J. R. Bergueiro. 2013. "Analysis of Oil Spill Risks in the Islands of Lanzarote and Fuerteventura Due to Exploration Under Adverse Weather Phenomena." Journal of Maritime Research 10(3):83-96.

Guillaumont, P. 2010. “Assessing the Economic Vulnerability of Small Island Developing States and the Least Developed Countries." Journal of Development Studies 46(5):828-854.

Höök, M. 2014. "Depletion Rate Analysis of Fields and Regions: A Methodological Foundation." Fuel 121(1):95-108.

Höök, M., B. Soderbergh, K. Jakobsson, and K. Aleklett. 2009. "The Evolution of Giant Oil Field Production Behavior." Natural Resources Research 18(1):39-56.

Iacono, R. 2016. "No Blessing, No Curse? On the Benefits of Being a Resource-Rich Southern Region of Italy." Research in Economics 70(2):346-359.

Ismail, K. 2010. "The Structural Manifestation of the 'Dutch Disease': The Case of Oil Exporting Countries." 
International Monetary Fund, working paper no. 10/103.

Kato, T., S. Omachi, and H. Aso. 2002. "Asymmetric Gaussian and Its Application to Pattern Recognition.” Pp. 405-413 in Structural, Syntactic, and Statistical Pattern Recognition SSPR/SPR 2002 Lecture Notes in Computer Science, vol. 2396, edited by T. Caelli, A. Amin, R. P. W. Duin, D. de Ridder, and M. Kamel. Springer Berlin Heidelberg.

Laherrère, J. H. 2000. "The Hubbert Curve: Its Strengths and Weaknesses." Oil and Gas Journal. Retrieved (http://dieoff. org/page191.htm).

Ley 8/2015 del Sector de Hidrocarburos (Law 8/2015 on the Hydrocarbon Sector). Boletín Oficial del Estado de España, Madrid, May 22, 2015.

Málaga, A. J. and J. P. Mayo. 2014. "Disparidades entre las Comunidades Autónomas Españolas en el Período 2007-2012” (Inequality in Spanish Regions, 2007-2012). Documento de trabajo, 2.9, VII Informe sobre Exclusión y Desarrollo Social en España 2014. Fundación Foessa.

Padrón Fumero, N., F. J. Ramos Real, R. Hernández Martín, and Y. Rodríguez Rodríguez. 2013. Turismo y Prospecciones Petroliferas en Canarias (Tourism and Oil Exploration in the Canary Islands). La Laguna: Cátedra de Turismo Caja Canarias-ASHOTEL-ULL. Retrieved (https://goo.gl/gZqdYh).

Rivero Ceballos, J. L. and S. Corral. 2014. "Oil and Gas Exploration in Waters Adjacent to the Canary Islands: An Economic Analysis in Terms of Uncertainty." Arethuse,
Scientific Journal of Economics and Business Management 2/2-2014:55-72.

Rocchi, B., C. Landi, G. Stefani, S. Romano, and M. Cozzi. 2015. "Escaping the Resource Curse in Regional Development: A Case Study on the Allocation of Oil Royalties." International Journal of Sustainable Development 18(1-2):115-138.

Sunley, E. M., T. Baunsgaard, and D. Simard. 2003. "Revenue From the Oil and Gas Sector: Issues and Country Experience." Pp. 153-183 in Fiscal Policy Formulation and Implementation in Oil-Producing Countries, edited by J. M. Davis, R. Ossowski, and A. Fedelino. Washington, D.C.: International Monetary Fund.

Taib, M. 2015. "The Mineral Industry of Morocco and Western Sahara." Pp. 30.1-30.12 in Minerals Yearbook 2013, Area Reports: International, vol. III. Washington, D.C.: U.S. Geological Survey.

van der Ploeg, F. 2011. "Natural Resources: Curse or Blessing?" Journal of Economic Literature 49(2):366-420.

World Bank. 2017. World Bank Commodity Forecast Price Data. Retrieved (https://goo.gl/rYMcGp).

\section{Bio}

Carmen D. Álvarez-Albelo, Ph.D., associate professor, Universidad de La Laguna, Spain; research fields: economic growth, tourism economics, international trade, general equilibrium. 